\title{
Transposition
}

Musique et Sciences Sociales

Musique : patrimoine immatériel ?

\section{Yves Balmer, Thomas Lacôte, Christopher Brent Murray, Le modèle et l'invention: Messiaen et la technique de l'emprunt}

Lyon, Symétrie, 2017

\section{Nigel Simeone}

\section{OpenEdition}

\section{Journals}

\section{Electronic version}

URL: http://journals.openedition.org/transposition/3069

DOI: 10.4000/transposition.3069

ISSN: $2110-6134$

Publisher

CRAL - Centre de recherche sur les arts et le langage

\section{Electronic reference}

Nigel Simeone, «Yves Balmer, Thomas Lacôte, Christopher Brent Murray, Le modèle et l'invention: Messiaen et la technique de l'emprunt », Transposition [Online], $8 \mid 2019$, Online since 15 September 2019, connection on 17 December 2020. URL : http://journals.openedition.org/transposition/3069 DOI : https://doi.org/10.4000/transposition.3069

This text was automatically generated on 17 December 2020.

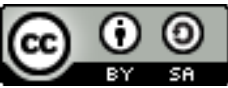

La revue Transposition est mise à disposition selon les termes de la Licence Creative Commons Attribution - Partage dans les Mêmes Conditions 4.0 International. 


\title{
Yves Balmer, Thomas Lacôte,
} Christopher Brent Murray, Le modèle et l'invention: Messiaen et la technique de l'emprunt

\author{
Lyon, Symétrie, 2017
}

Nigel Simeone

\section{REFERENCES}

Yves Balmer, Thomas Lacôte, Christopher Brent Murray, Le modèle et l'invention:

Messiaen et la technique de l'emprunt, Lyon, Symétrie, 2017, 607 p.

1 This is an important and engrossing book: it will be essential reading for anybody wanting to delve into Messiaen's creative processes beyond the composer's own writings on his works (texts that are sometimes more notable for their length than for any insights into how he went about composing). Moreover, this detailed study by Balmer, Lacôte and Murray, very well illustrated with almost 500 musical examples, is a publication that should be of interest to anybody investigating models, influences and borrowings in the work of other composers. It's a formidable achievement and the reasons for its success are not hard to find: seeking to trace or explain influence is sometimes rather an ill-defined exercise in imprecision and generalisation, but here it is explored with forensic detail and supported by ample evidence. While there have been occasional references to Messiaen's borrowings, a great deal of what this book has to tell us is new to the Messiaen literature. Over the last decade or so, these three scholars have pursued their subject with admirable tenacity and the results are often revelatory.

2 To set matters in a broader context, it's hard to find a composer who isn't a borrower of one sort or another, whether from sources such as folk tunes, earlier art music, or ideas 
encountered by chance (though how much credence we give to the story of Mozart's starling singing the tune that became the finale of the $G$ major Piano Concerto K453 is another matter). In the twentieth century, Stravinsky borrowed in any number of ways: from Russian folk music, from specific compositions by other composers, and, in one famous case accidentally plagiarising the whole chorus of a song written in 1908 ('La jambe en bois' by Émile Spencer) in Petrushka, which was completed three years later. Indeed, Petrushka is a well-documented treasure-trove of borrowings: as well as incorporating several folk tunes, it also includes two waltzes by Joseph Lanner. Among other composers, Vaughan Williams and Holst both explicitly acknowledged the musical influence each had on the other, quite aside from their warm personal friendship. Some works by Ives are assembled from a dizzying array of musical objets trouvés ranging from American hymnody to marching bands. Other composers are serial self-borrowers, prominent among them the likes of Poulenc (countless examples of recurring phrases, often from works written decades earlier) and Bernstein (the Chichester Psalms was entirely assembled from earlier music originally intended for the theatre).

3 In other words, there's nothing unusual about Messiaen being a composer who also borrowed prolifically from the work of others. Nor is there anything odd about Messiaen himself saying nothing about this: composers almost always keep this sort of thing to themselves unless they are writing a piece that's a specific homage to a colleague or predecessor. But what is remarkable is that Messiaen said so much about his music, indulging in a kind of self-analysis that gives the appearance of being more exhaustive than any of his contemporaries. This took the form of specific commentaries (often printed as prefaces to the published scores) and two important theoretical works: Technique de mon langage musical (1944) and the immense Traité de rythme, de couleur, et d'ornithologie (1994-2002, drawing on some material which stretches back to the late 1940s). Balmer, Lacôte and Murray divide their study into considerations of melodic, harmonic and rhythmic borrowings before turning to specific chapters on borrowings from Debussy, Ravel, Massenet, Jolivet, Honegger, Stravinsky and several others, as well as Messiaen's engagement with plainchant and folkloric material, with borrowings from the eighteenth century (prompting a question: 'Was Messiaen a neo-classicist?' (p. 450-455)). Finally, some specific passages in Messiaen's music - and the debt they owe to other models - are examined in detail: Les Corps glorieux, Cinq Rechants, Turangalîla and Visions de l'Amen. These are truly fascinating. In their consideration of the 'Amen des Anges' from Visions de l'Amen, the authors explore borrowings from sources as diverse as Ravel (Ma mère l'Oye), Indian traditional music, and a Russian folk song (published in a French collection) as a possible inspiration for the 'Theme of Creation'. But at the same time, these case studies also examine Messiaen's composing process - the ways in which he developed, extended and varied ideas - with greater clarity, precision and thoroughness than any previous study of Messiaen's music.

While Messiaen spoke openly about the influence of Chopin (Barcarolle) and Albéniz (Iberia) on the development of his piano writing, and of the impact Debussy's Pelléas et Mélisande made on him, he was much more reticent - in fact pretty much silent - when it came to borrowings from his contemporaries. The importance of Ravel as a resource in the development of Messiaen's harmonic language is something that has not, I think, been explored in any detail before - and was something Messiaen himself spoke about only in the most general terms. Here we are presented with examples from passages in 
the Histoires naturelles and Le Tombeau de Couperin (among others) which were borrowed, refashioned and transformed for Messiaen's own purposes in Les Corps glorieux and the Quatuor pour la fin $d u$ Temps. The borrowings from Messiaen's friend Jolivet - two of the musical musketeers that made up the Groupe Jeune France in the 1930s - are even more startling. Jolivet was a composer about whom Messiaen spoke in admiring terms, illustrating particular features of his work in the Traité de rythme, but not spelling out just how important some of Jolivet's innovations were for Messiaen's own works. This book presents significant borrowings of Jolivet's ideas in Cantéyodjayâ and a remarkable array of other Jolivet harmonic and technical devices that Messiaen silently borrowed for his own purposes.

5 As I said at the start of the review, this kind of borrowing shouldn't surprise us, but the singular achievement of Balmer, Lacôte and Murray is the meticulous care with which Messiaen's instances of borrowing are demonstrated and explored. Equally intriguing are the catalogue of borrowings from composers as different as Massenet, Stravinsky and Tournemire. This book will serve as an invaluable reference point for anyone exploring Messiaen's harmonic language and his use of particular musical gestures. That it has been done so well is cause for rejoicing: Le modèle et l'invention is an outstanding book in every way, a landmark in the stylistic study - and deeper understanding - of a great twentieth century composer.

\section{AUTHOR}

\section{NIGEL SIMEONE}

Nigel Simeone is a musicologist. He is the co-author of Messiaen (Yale, 2005; French edition: Fayard, 2008), awarded the 2008 Prix René Dumesnil by the Académie des Beaux-Arts for the best music book of the year. He is also the author of a catalogue of Messiaen's works and of numerous articles on the composer. As well as twentieth century French music, his particular specialisms include the music of Leoš Janáček: he co-authored Janáček's Works (Oxford, 1997) and his most recent book is The Janáček Compendium (Boydell, 2019). He has also worked on the composerconductor Leonard Bernstein and edited The Leonard Bernstein Letters (Yale, 2013) as well as writing Leonard Bernstein: West Side Story (Ashgate, 2009) for the series Landmarks in Music Since 1950. His other interests include the history of conducting and British music since 1900. 